\title{
Preventive Effect of SA13353, a Novel Transient Receptor Potential Vanilloid 1 Agonist, on Ischemia/Reperfusion-Induced Renal Injury in Rats
}

\author{
Kyoko Ueda ${ }^{1}$, Fumio Tsuji ${ }^{2, *}$, Tomoko Hirata ${ }^{1}, K$ Kenji Ueda ${ }^{2}$, Masaaki Murai $^{2}$, Hiroyuki Aono ${ }^{2}$, \\ Masanori Takaoka ${ }^{1}$, Yasuo Matsumura ${ }^{1}$ \\ ${ }^{1}$ Laboratory of Pathological and Molecular Pharmacology, Osaka University of Pharmaceutical Sciences, Japan \\ ${ }^{2}$ Research \& Development Center, Santen Pharmaceutical Co., Ltd., Japan
}

Copyright $(2015$ Horizon Research Publishing All rights reserved.

\begin{abstract}
Tumor necrosis factor (TNF)- $\alpha$ plays a crucial role in the pathogenesis of ischemia/reperfusion-induced renal injury. We demonstrated recently that the preischemic treatment with resiniferatoxin, a transient receptor potential vanilloid 1 (TRPV1) agonist, attenuates renal TNF- $\alpha$ mRNA expression, and improves ischemia/reperfusion-induced renal injury in rats. In the present study, we investigated effects of treatment with SA13353, a novel orally active TRPV1 agonist, on ischemia/reperfusion-induced renal injury in rats. Ischemic acute kidney injury (AKI) was induced by occlusion of the left renal artery and vein for 45 min followed by reperfusion, 2 weeks after contralateral nephrectomy. Renal function in vehicle-treated AKI rats markedly decreased at $24 \mathrm{~h}$ after reperfusion. Treatment with SA13353 (3, 10, and $30 \mathrm{mg} / \mathrm{kg}$, p.o.) $30 \mathrm{~min}$ before ischemia dose-dependently attenuated the ischemia/reperfusion-induced renal dysfunction. Histopathological examination of the kidney of AKI rats revealed severe renal damage, which were significantly suppressed by the SA13353 treatment. In renal tissues exposed to ischemia/reperfusion, TNF- $\alpha$ and cytokine-induced neutrophil chemoattractant-1 mRNA expressions were augmented, but these alterations were attenuated by the treatment with SA13353. On the other hand, ischemia/reperfusion-enhanced renal interleukin-10 mRNA expression and its plasma concentration were further augmented by SA13353 treatment. These results demonstrate that the orally active TRPV1 agonist SA13353 prevents the ischemia/reperfusion-induced AKI. This renoprotective effects seem to be closely related to the inhibition of inflammatory response via TRPV1 activation.
\end{abstract}

Keywords TRPV1, SA13353, Ischemia/Reperfusion, Acute Kidney Injury

\section{Introduction}

Ischemic cell injury in the kidney occurs during cardiovascular surgery, shock, and transplantation, which may lead to acute kidney injury (AKI). In an international investigation of the epidemiology of AKI, the period prevalence of AKI requiring renal replacement therapy in intensive care unit was approximately $5 \%$ and the hospital mortality was more than $50 \%$ [1]. Renal ischemia, followed by reperfusion, is one of the most common causes of AKI and places a significant burden on the health care system. AKI is caused by ischemic and nephrotoxic insults acting alone or in combination. It is associated with increased morbidity, prolonged hospitalizations, and increased mortality [2]. The renal tubules are susceptible to hypoxic injury because of a number of factors, but they are also capable of rapid regeneration and functional recovery. The molecular mechanisms underlying ischemia/reperfusion-induced renal injury are not fully understood, but it has been reported that several causal factors (e.g., tumor necrosis factor (TNF)- $\alpha$ mRNA expression, ATP depletion, enhancement of reactive oxygen species production, phospholipase activation, neutrophil infiltration, vasoactive peptides etc.) are contributive to the pathogenesis of this renal damage [3]. Among them, TNF- $\alpha$ is released during renal ischemia/reperfusion and plays an important role in the ensuing neutrophil-mediated kidney injury [4]. TNF- $\alpha$ up-regulates neutrophil adhesion molecules, in particular intercellular adhesion molecule-1, after renal ischemia/reperfusion, and this molecule then plays an important role in tissue neutrophil influx. Accumulating evidence indicates that renal TNF- $\alpha$ is an autocrine contributor to renal dysfunction induced by the ischemia/reperfusion [5]. On the other hand, the anti-inflammatory cytokine interleukin (IL)-10, which is a potent inhibitor of fever generation and early phase inflammation, has many effects such as inhibition of cytokines, chemokines, and neutrophil activation [6]. In addition, IL-10 has been shown recently to improve ischemic and cisplatin-induced AKI, by inhibiting the maladaptive 
activation of genes that cause leukocyte activation and adhesion [7].

Transient receptor potential vanilloid 1 (TRPV1), formerly termed vanilloid receptor 1 , is a nonselective cation channel that can be activated by noxious heat, protons, and vanilloids such as capsaicin [8], and a range of putative endogenous mediators [9]. TRPV1 was known originally to be associated with nociceptive primary afferent fibers, but subsequent observations revealed that it is broadly expressed in the brain, epidermis and visceral cells [10]. It is controversial that TRPV1 agonists act as aggravators of inflammation or inhibitors of it. Keeble et al. [11] and Szabó et al. [12] have demonstrated that TRPV1 plays a potential role in acute and chronic inflammation in the knee joint. In contrast, Kissin et al. [13] have shown that resiniferatoxin, a potent capsaicin analog, attenuates knee joint inflammation. Small doses of capsaicin are known to reduce systemic inflammatory responses in septic rats [14]. Moreover, it has been demonstrated that lipopolysaccharide-induced systemic endotoxemia and airway inflammation are augmented in TRPV1-knockout mice, thereby suggesting the protective role of TRPV-mediated action against the onset of sepsis after endotoxin and endotoxin-induced airway inflammation $[15,16]$. A recent study demonstrated that the recovery process of ischemia/reperfusion-induced cardiac dysfunction was impaired in TRPV1 gene knockout mice [17].

TRPV1 expression is seen in a high percentage of primary afferent neurons that project to cardiovascular and renal tissues [18]. It has been demonstrated most recently that TRPV1 protein is highly present in the renal pelvis and exclusively regulates neuropeptide release from primary renal afferent nerves in response to mechanostimulation [19]. Moreover, TRPV1 protein is abundantly located in renal tubules of medulla, although its functional roles are unknown [19]. The renal medulla contains nephron segments that are most susceptible to ischemic injury [20]. We have obtained evidence recently that the TRPV1 agonists capsaicin and resiniferatoxin attenuate renal TNF- $\alpha$ mRNA, increase renal IL-10 mRNA expression, and improve ischemia/reperfusion-induced renal injury in rats [21]. SA13353

(1-[2-(1-Adamantyl)ethyl]-1-pentyl-3-[3-(4-pyridyl)propyl] urea) was originally identified by us as a potent and orally active inhibitor of TNF- $\alpha$ production, and this effect was due to the activation of capsaicin-sensitive afferent neurons mediated via TRPV1 in vivo [22]. In the present study, we investigated the effects of treatment with the TRPV1 agonist, SA13353, on the ischemic AKI in rats and evaluated the possible involvement of TNF- $\alpha$ and IL-10, and cytokine-induced neutrophil chemoattractant (CINC)-1 in the SA13353-induced actions.

\section{Materials and Methods}

\subsection{Drugs}

SA13353 was synthesized at Santen Pharmaceutical Co., Ltd. (Nara, Japan), and suspended in 1\% methylcellulose solution for oral administration. ${ }^{14} \mathrm{C}$-radiolabeled SA13353 $\left({ }^{14} \mathrm{C}-\mathrm{SA} 13353\right)$ was synthesized by GE Healthcare (Chalfont St. Giles, UK). The radiochemical purity of ${ }^{14} \mathrm{C}$-SA13353 in dose formulation was $>97 \%$.

\subsection{Screenings for the Target Molecules of SA13353}

To identify the target molecules of SA13353, 82 binding assays and 37 enzyme (except for TNF- $\alpha$ converting enzyme) assays were performed by Cerep (Poitiers, France) or MDS Sciex (Concord, ON, Canada). TNF- $\alpha$ converting enzyme assay was performed in Santen Pharmaceutical Co., Ltd.

\subsection{Pharmacokinetic Analysis of SA13353}

To support identifying the target molecules of SA13353, we measured plasma concentrations of SA13353 in rats. Blood samples were collected at $0.25,0.5,1,2,4$ and $24 \mathrm{~h}$ from the cervical vein, with syringes containing heparin sodium after oral administration of SA13353 at a dose of 30 $\mathrm{mg} / \mathrm{kg}$. Plasma was separated immediately by centrifugation and stored at $-70^{\circ} \mathrm{C}$ or below. Experimental protocols and animal care methods in the experiments were approved by the Santen Animal Experimental Ethics Committee. Considering the pharmacological study, male Sprague-Dawley rats (10 weeks of age, Japan SLC, Shizuoka, Japan) weighing 280 to $320 \mathrm{~g}$ were used. The animals were housed in a light-controlled room with a 12 -h light/dark cycle and were allowed ad libitum access to food and water. All animals abstained from food for $12 \mathrm{~h}$ before the administration of SA13353. Plasma concentrations of SA13353 were determined using liquid chromatography with tandem mass spectrometry with validated method. The calibration curve is linear up to $25 \mathrm{ng} / \mathrm{mL}$ with a lower limit of quantification of $0.2 \mathrm{ng} / \mathrm{mL}$. Interday accuracy and precision measured as coefficients of variation and relative errors of mean values were 2.2 to $11.5 \%$ and 0.6 to $10.0 \%$, respectively.

\subsection{Excretion Route of SA13353}

After oral administration of ${ }^{14} \mathrm{C}-\mathrm{SA} 13353(3 \mathrm{mg} / \mathrm{kg})$ to male rats, urine and feces were collected separately from each animal until $168 \mathrm{~h}$ postdose. Any ${ }^{14} \mathrm{CO}_{2}$ present in the expired air was trapped in a mixture of ethanolamine/2-ethoxyethanol $(1: 3, \mathrm{v} / \mathrm{v})$ until $120 \mathrm{~h}$ after dose. The interiors of the metabolism cages were washed well with distilled water throughout the sample collection period, and the washings were retained. The rats were housed individually in glass metabolism cages after dosing and allowed ad libitum access to food and water under lighting controlled with a 12-h light/dark cycle. Urine, air traps, and cage washings were mixed with Ultima Gold Scintillator (Canberra Packard Ltd., Meriden, CT, USA) for measurement of radioactivity concentrations. Feces were 
homogenized with 1.5 volumes of distilled water and burned in oxygen using an Automatic Sample Oxidizer (model 307; Canberra Packard Ltd). The products of combustion were absorbed in Carbo-sorb E and mixed with Permafluor E+ (Canberra Packard Ltd.) for measurement of radioactivity concentrations. Radioactivity was measured by liquid scintillation analysis using Wallac 1409 automatic liquid scintillation counters (PerkinElmer Life and Analytical Sciences-Wallac Oy, Turku, Finland).

\subsection{Animals and Experimental Designs}

Male Sprague-Dawley rats (10 weeks of age; Japan SLC) weighing 280 to $320 \mathrm{~g}$ were used. The animals were housed in a light-controlled room with a 12-h light/dark cycle and were allowed ad libitum access to food and water. Experimental protocols and animal care methods in the experiments were approved by the Experimental Animal Research Committee at Osaka University of Pharmaceutical Sciences. Two weeks before the study (at 8 weeks of age), the right kidney was removed through a small flank incision under pentobarbital anesthesia $(50 \mathrm{mg} / \mathrm{kg}$ i.p. $)$. After a 2-week recovery period, uninephrectomized rats were divided into sham-operated control, vehicle-treated ischemic AKI, and drug-treated ischemic AKI groups. These all animals abstained from food for $12 \mathrm{~h}$ before the ischemia. To induce ischemic AKI, the rats were anesthetized with pentobarbital $(50 \mathrm{mg} / \mathrm{kg}$ i.p.), and the left kidney was exposed through a small flank incision. The left renal artery and vein were occluded with a nontraumatic clamp for 45 min. At the end of the ischemic period, the clamp was released for blood reperfusion. SA13353 (3, 10, and 30 $\mathrm{mg} / \mathrm{kg}$ ) and its vehicle (1\% methylcellulose) were given orally $30 \mathrm{~min}$ before the start of ischemia at a volume 5 $\mathrm{mL} / \mathrm{kg}$. In sham-operated control animals, the left kidney was treated identically, except for the clamping. All these surgical procedures were carefully done under the rectal temperature-controlled condition using a heater. The animals exposed to $45 \mathrm{~min}$ of ischemia were housed in metabolic cages $24 \mathrm{~h}$ after reperfusion; 5-h urine samples were taken, and blood samples were drawn from the thoracic aorta at the end of the urine collection period. The plasma was separated by centrifugation. These samples were used for measurements of renal function parameters. The kidneys were excised and examined using a light microscope.

In separate experiments, animals were sacrificed at various time points after the start of reperfusion for evaluation of mRNA expressions and plasma concentration of IL-10. Renal TNF- $\alpha$ and IL-10 mRNA expression and plasma IL-10 concentration were determined at 2 and $4 \mathrm{~h}$ after the reperfusion, based on our recent study [21].

\subsection{Renal Functional Parameters}

Blood urea nitrogen (BUN) and plasma creatinine concentration (Pcr) were determined using a commercial assay kit, the BUN-test-Wako, and Creatinine-test-Wako
(Wako Pure Chemicals, Osaka, Japan), respectively. Urine and plasma sodium concentrations were determined using a flame photometer (205D; Hitachi, Hitachinaka, Japan). The fractional excretion of sodium $\left(\mathrm{FE}_{\mathrm{Na}}\right.$; percentage) was calculated from the following formula: $\mathrm{FE}_{\mathrm{Na}}=\mathrm{U}_{\mathrm{Na}} \mathrm{V} /\left[\mathrm{P}_{\mathrm{Na}} \times\right.$ creatinine clearance $(\mathrm{Ccr})] \times 100$, where $\mathrm{U}_{\mathrm{Na}} \mathrm{V}$ is the urinary excretion of sodium, and $\mathrm{P}_{\mathrm{Na}}$ is the plasma sodium concentration.

\subsection{Histological Studies}

Excised left kidneys were processed for light microscopic observation, according to standard procedures. The kidneys were then fixed in phosphate-buffered $10 \%$ formalin, after which the kidneys were chopped into small pieces, embedded in paraffin wax, cut at $4 \mu \mathrm{m}$, and stained with hematoxylin and eosin. Histopathological changes were analyzed for tubular necrosis and medullary congestion, as described previously [23]. Tubular necrosis was graded as follows: no damage (0), mild (1, unicellular, patchy isolated damage), moderate (2, damage less than $25 \%$ ), severe (3, damage between 25 and $50 \%$ ), and very severe (4, more than $50 \%$ damage). The degree of medullary congestion was defined as: no congestion (0), mild (1, vascular congestion with identification of erythrocytes by $\times 400$ magnification), moderate (2, vascular congestion with identification of erythrocytes by $\times 200$ magnification), severe (3, vascular congestion with identification of erythrocytes by $\times 100$ magnification), and very severe (4, vascular congestion with identification of erythrocytes by $\times 40$ magnification). The scoring of the histological data was performed by independent observers in a double-blind manner.

\subsection{Total RNA Extraction, Reverse Transcription and Real-Time PCR}

Total RNA was isolated from left kidney of sham-operated control, vehicle-treated ischemic AKI, and drug-treated ischemic AKI groups using commercially available kit (Nippon Gene, Tokyo, Japan) following the manufacturer's instructions. Total RNA was then reverse transcribed using a commercially available kit (Takara Bio, Otsu, Japan). Ten microliters of reaction mixture containing $500 \mathrm{ng}$ of total RNA was incubated at $42^{\circ} \mathrm{C}$ for $15 \mathrm{~min}$ for reverse transcription, then reverse transcriptase was inactivated by incubation at $95^{\circ} \mathrm{C}$ for $2 \mathrm{~min}$. For real-time $\mathrm{PCR}$, the primers used were as follows: ribosomal protein S18 (Rps18) forward, 5'-AAGTTTCAGCACATCCTGCGAGTA-3'; Rps18 reverse, 5'-TTGGTGAGGTCAATGTCTGCTTTC-3'; TNF- $\alpha$ forward, 5'-AACTCGAGTGACAAGCCCGTAG-3'; TNF- $\alpha$ reverse, 5'-GTACCACCAGTTGGTTGTCTTTGA-3'; IL-10 forward, 5'-CAGACCCACATGCTCCGAGA-3'; IL-10 reverse, 5'-CAAGGCTTGGCAACCCAAGTA-3'; CINC-1 forward, 5'-AGGCTTGCCTTGACCCTGAA-3'; CINC-1 
reverse, 5'-ACGCCATCGGTGCAATCTATC-3'. All primers were purchased from Takara Bio. The PCR reactions were carried out in an ABI Prism 7000 (Applied Biosystems, Foster City, CA, USA). Reverse transcriptase-PCR amplifications were performed in a volume of $50 \mu \mathrm{L}$. Each reaction mixture contained $2 \mu \mathrm{L}$ of cDNA, $25 \mu \mathrm{l}$ of SYBR Green PCR master mix (QIAGEN $\mathrm{GmbH}$, Hilden, Germany), and $0.5 \mu \mathrm{M}$ each primer. Each reverse transcriptase-PCR run started with a $15-\mathrm{min}$ period at $95^{\circ} \mathrm{C}$ to activate the Taq polymerase. The amplification was done for 45 cycles. Each cycle consisted of: denaturation for $15 \mathrm{~s}$ at $94^{\circ} \mathrm{C}$, annealing of primers for $30 \mathrm{~s}$ at 55 or $58^{\circ} \mathrm{C}$, and elongation for $30 \mathrm{~s}$ at $72^{\circ} \mathrm{C}$. The mRNA copy numbers were calculated from the cycle threshold value using ABI Prism 7000 Sequence Detection System (Applied Biosystems). Results of mRNA copy numbers were normalized against Rps18 mRNA.

\subsection{Measurements of IL-10 and CINC-1 Protein}

Plasma concentrations of IL-10 and CINC-1 were measured using Bio-Plex suspension system (Biorad, Hercules, CA, USA).

\subsection{Statistical Analysis}

Values are expressed as the mean \pm S.E.M. Relevant data were processed by InStat (GraphPad Software Inc., San Diego, CA, USA). For statistical analysis, we used one-way analysis of variance followed by Dunnett's tests for multiple comparisons. Histological data were analyzed using the Mann-Whitney test. For all comparisons, differences were considered significant at $P<0.05$.

\section{Results}

\subsection{Screenings for the Target Molecules of SA13353}

Although SA13353 was inactive $(<50 \%$ inhibition at 1 $\mu \mathrm{M}$ ) to most of the tested targets (except for histamine $\mathrm{H}_{2}$ receptor), the compound showed a binding affinity for the rat vanilloid receptor, a candidate target molecule (Table 1). At present, we cannot explain the pharmacological implications of SA13353 with $\mathrm{H}_{2}$ receptors. An $\mathrm{IC}_{50}$ value of SA13353 for rat vanilloid receptor was $191 \pm 28 \mathrm{nM}$ (mean of three independent experiments). Taking into account the $\mathrm{Kd}$ value for the radioligand $(0.046 \mathrm{nM})$, the $\mathrm{Ki}$ value for SA13353 was $35.8 \pm 5.2 \mathrm{nM}$. Capsaicin, the reference for the TRPV1 agonist [8], showed a binding affinity for this receptor with an $\mathrm{IC}_{50}$ value of $3140 \mathrm{nM}$.

\subsection{Pharmacokinetics and Excretion Route of SA13353}

Plasma concentration of SA13353 peaked at 0.5 to $1 \mathrm{~h}$ after oral administration and thereafter decreased gradually (Figure 1A). The mean $\mathrm{C}_{\max }$ and $\mathrm{T}_{\max }$ values of SA13353 after oral administration at a dose of $30 \mathrm{mg} / \mathrm{kg}$ were $476 \pm$ $135 \mathrm{nM}$ and $0.63 \pm 0.13 \mathrm{~h}$, respectively, and mean area under the plasma concentration-time curve from 0 to $24 \mathrm{~h}$ calculated by the linear trapezoidal rule was $3970 \pm 860$ $\mathrm{nM} \cdot \mathrm{h}$. After oral doses of ${ }^{14} \mathrm{C}-\mathrm{SA} 13353(3 \mathrm{mg} / \mathrm{kg})$ to male rats, $85.09 \pm 1.90$ and $8.96 \pm 1.50 \%$ of the radioactivity dose were excreted in the feces and urine, respectively, during the 7-day sample collection period, indicating that SA13353 was predominantly excreted into feces (Figure 1B). The recovery of radioactivity in feces, urine, expired air traps and cage washings was $95.44 \pm 1.76 \%$ of dose during this period. Therefore, we considered that the urinary excretion route is minor, and there is no effect of uninephrectomy on pharmacokinetics of SA13353. In addition, there were not more potent active metabolites than SA13353, and plasma concentrations of metabolites were not higher than that of SA13353 (data not shown). Taking into account the results of the binding and enzyme assays, SA13353 seems to be a near-pure TRPV1 agonist in this study.
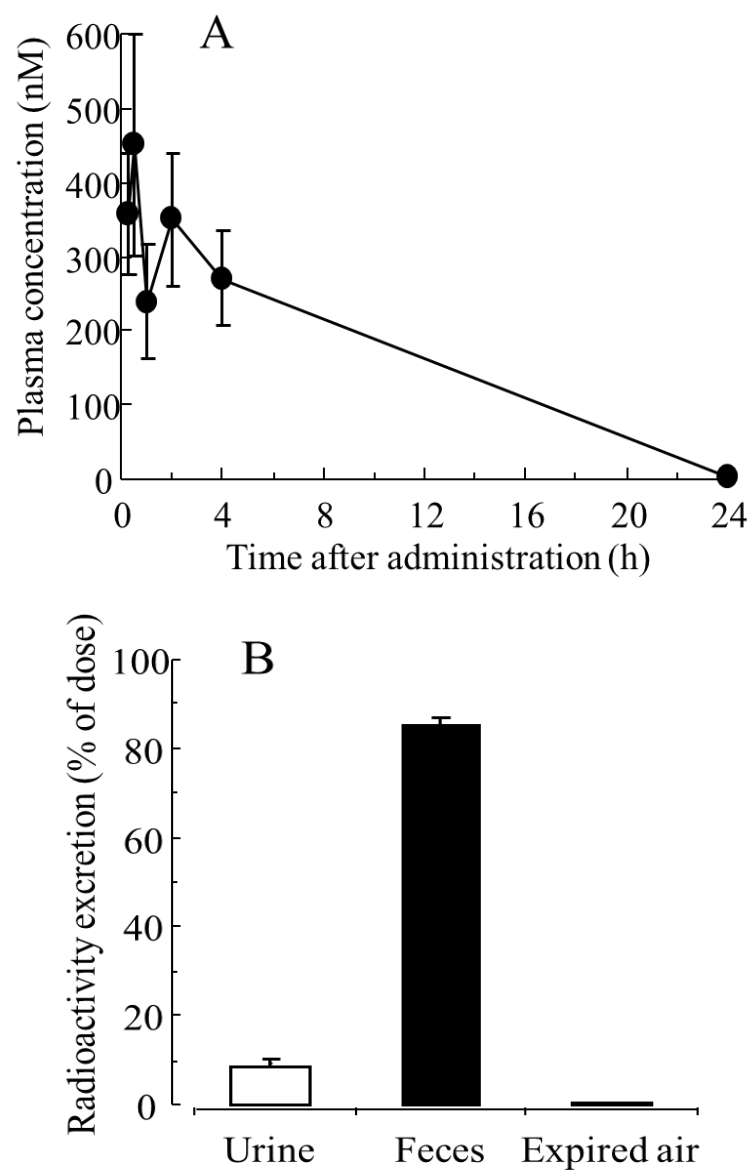

Figure 1. Plasma concentrations of SA13353 (A) and radioactivity excretions until $168 \mathrm{~h}$ (B) after oral administration $(30 \mathrm{mg} / \mathrm{kg})$. Each point and bar represents the mean \pm S.E.M. of 4 animals 

on Ischemia/Reperfusion-Induced Renal Injury in Rats

Table 1. Results of binding, enzyme inhibitory, and functional assay of SA13353

\begin{tabular}{|c|c|c|c|}
\hline Receptor/lon Channel/Enzyme & $\%$ Inhibition at $1 \mu \mathrm{M}$ & Reference compound & $\mathrm{IC}_{50}(\mathrm{nM})$ \\
\hline Adenosine $A_{1}(h)$ & - & DPCPX & 37 \\
\hline Adenosine $A_{2 A}(h)$ & - & NECA & 33 \\
\hline Adenosine $A_{3}(h)$ & - & IB-MECA & 1.9 \\
\hline Adrenergic $\alpha_{1}$ (non-selective) & - & Prazosin & 0.60 \\
\hline Adrenergic $\alpha_{2}$ (non-selective) & - & Yohimbine & 57 \\
\hline Adrenergic $\beta_{1}(\mathrm{~h})$ & - & Atenolol & 2000 \\
\hline Adrenergic $\beta_{2}(\mathrm{~h})$ & - & $\mathrm{ICl} 118551$ & 3.5 \\
\hline Angiotensin $\mathrm{AT}_{1}(\mathrm{~h})$ & - & Saralasin & 1.1 \\
\hline Angiotensin $\mathrm{AT}_{2}(\mathrm{~h})$ & - & Saralasin & 0.70 \\
\hline Benzodiazepine (central) & - & Diazepam & 26 \\
\hline Bradykinin $B_{1}(h)$ & - & $\operatorname{des} \operatorname{Arg}^{10}-K D$ & 0.89 \\
\hline Bradykinin $\mathrm{B}_{2}(\mathrm{~h})$ & - & NPC567 & 6.0 \\
\hline Calcitonin (h) & - & Calcitonin & 0.32 \\
\hline Calcitonin Gene-Related Peptide CGRP 1 (h) & - & CGRP $\alpha$ & 0.045 \\
\hline Cannabinoid $\mathrm{CB}_{1}(\mathrm{~h})$ & - & WIN55212-2 & 15 \\
\hline Cannabinoid $\mathrm{CB}_{2}(\mathrm{~h})$ & - & WIN55212-2 & 5.6 \\
\hline Cholecystokinin $\mathrm{CCK}_{1}(\mathrm{~h})$ & - & CCK-8 & 1.1 \\
\hline Cholecystokinin $\mathrm{CCK}_{2}$ & - & CCK-8 & 0.80 \\
\hline Corticotropin Releasing Factor $\mathrm{CRF}_{1}$ & - & CRF & 2.5 \\
\hline Dopamine $D_{1}(h)$ & - & $\mathrm{SCH} 23390$ & 1.0 \\
\hline Dopamine $\mathrm{D}_{2 \mathrm{~S}}(\mathrm{~h})$ & - & (+)Butaclamol & 10 \\
\hline Dopamine $\mathrm{D}_{3}(\mathrm{~h})$ & - & (+)Butaclamol & 15 \\
\hline Dopamine $\mathrm{D}_{4.4}(\mathrm{~h})$ & - & Clozapine & 92 \\
\hline Endothelin $\mathrm{ET}_{\mathrm{A}}(\mathrm{h})$ & - & Endothelin-1 & 0.091 \\
\hline Endothelin $\mathrm{ET}_{\mathrm{B}}(\mathrm{h})$ & - & Endothelin-3 & 0.090 \\
\hline GABA (non-selective) & - & GABA & 45 \\
\hline Galanin $\mathrm{GAL}_{1}(\mathrm{~h})$ & - & Galanin & 0.062 \\
\hline Galanin $\mathrm{GAL}_{2}(\mathrm{~h})$ & - & Galanin & 2.67 \\
\hline Glucagon-Like Peptide GLP-1 (h) & - & GLP-1 (7-36) amide & 0.12 \\
\hline Glutamate AMPA & - & L-glutamate & 800 \\
\hline Glutamate Kainate & - & Kainic acid & 16 \\
\hline Glutamate NMDA & - & CGS 19755 & 710 \\
\hline Glutamate PCP & - & MK801 & 12 \\
\hline Histamine $\mathrm{H}_{1}$ (central) & - & Pyrilamine & 3.8 \\
\hline Histamine $\mathrm{H}_{2}$ & 53 & Cimetidine & 2300 \\
\hline Histamine $\mathrm{H}_{3}$ & - & (R) $\alpha$-Me-histamine & 2.4 \\
\hline Imidazoline I1 (peripheral) & - & Rilmenidine & 390 \\
\hline Imidazoline I2 (central) & - & Idazoxan & 4.3 \\
\hline Leukotriene LTD4 (h) & - & LTD4 & 2 \\
\hline Melanocortin MC4 (h) & - & NDP-a-MSH & 0.2 \\
\hline Muscarinic M (non-selective) & - & Atropine & 0.31 \\
\hline
\end{tabular}

Table shows the inhibition $\%$ of SA13353 at $1 \mu \mathrm{M}$ and $\mathrm{IC}_{50}$ value of reference compound for each target.

$-:<50 \%$ inhibition at $1 \mu \mathrm{M}$. 
Table 1. Results of binding, enzyme inhibitory, and functional assay of SA13353 (continued)

\begin{tabular}{|c|c|c|c|}
\hline Receptor/lon Channel/Enzyme & $\%$ Inhibition at $1 \mu \mathrm{M}$ & Reference compound & $\mathrm{IC}_{50}(\mathrm{nM})$ \\
\hline Neurokinin $\mathrm{NK}_{1}(\mathrm{~h})$ & - & {$\left[\operatorname{Sar}^{9}, \operatorname{Met}\left(\mathrm{O}_{2}\right)^{11}\right]-\mathrm{SP}$} & 0.32 \\
\hline Neurokinin $\mathrm{NK}_{2}(\mathrm{~h})$ & - & {$\left[\mathrm{Nle}^{10}\right]-\mathrm{NKA}(4-10)$} & 23 \\
\hline Neurokinin $\mathrm{NK}_{3}(\mathrm{~h})$ & - & SB222200 & 28 \\
\hline Neuropeptide $Y$ (non-selective) & - & NPY & 1.1 \\
\hline Nicotinic $N$ (neuronal) ( $\alpha$-BGTX-insensitive) & - & Nicotine & 18 \\
\hline Nicotinic N (neuronal) ( $\alpha$-BGTX-sensitive) & - & $\alpha$-Bungarotoxin & 2.2 \\
\hline Opiate (non-selective) & - & Naloxone & 2.7 \\
\hline ORL1 (h) (NOP) & - & Nociceptin & 5.9 \\
\hline Purinergic $\mathrm{P} 2 \mathrm{X}$ & - & $\alpha, \beta$-MeATP & 23 \\
\hline Purinergic $\mathrm{P} 2 \mathrm{Y}$ & - & dATP $\alpha S$ & 44 \\
\hline Serotonin 5-HT (non-selective) & - & Serotonin & 1.4 \\
\hline Sigma (non-selective) & - & Haloperidol & 36 \\
\hline Steroid AR (h) & - & Mibolerone & 4.7 \\
\hline Steroid ER (h) & - & $17-\beta$-estradiol & 1.9 \\
\hline Steroid GR (h) & - & Dexamethasone & 1.6 \\
\hline Steroid GR & - & Dexamethasone & 7.1 \\
\hline Steroid PR (h) & - & R5020 & 5.6 \\
\hline Somatostatin sst ${ }_{1}(\mathrm{~h})$ & - & Somatostatin-14 & 0.36 \\
\hline Somatostatin $\mathrm{sst}_{2}(\mathrm{~h})$ & - & Somatostatin-14 & 0.012 \\
\hline Somatostatin $\mathrm{sst}_{3}(\mathrm{~h})$ & - & Somatostatin-14 & 0.075 \\
\hline Somatostatin sst $\mathrm{s}_{4}(\mathrm{~h})$ & - & Somatostatin-14 & 1 \\
\hline Somatostatin sst ${ }_{5}(\mathrm{~h})$ & - & Somatostatin-14 & 0.14 \\
\hline Thyrotropin Releasing Hormone TRH & - & $\mathrm{TRH}$ & 52 \\
\hline Vanilloid & 98 & Resiniferatoxin & 0.60 \\
\hline Vasoactive Intestinal Peptide $\mathrm{VIP}_{1}(\mathrm{~h})$ & - & VIP & 0.076 \\
\hline Vasopressin $V_{1 a}(h)$ & - & {$\left[\mathrm{d}\left(\mathrm{CH}_{2}\right)_{5}{ }^{1}, \mathrm{Tyr}(\mathrm{Me})_{2}\right]-\mathrm{AVP}$} & 2.5 \\
\hline Vasopressin $V_{2}(h)$ & - & AVP & 1.6 \\
\hline $\mathrm{Ca}^{2+}$ channel (L, DHP site) & - & Nitrendipine & 3.7 \\
\hline $\mathrm{Ca}^{2+}$ channel (L, diltiazem site) (benzothiazepines) & - & Diltiazem & 27 \\
\hline $\mathrm{Ca}^{2+}$ channel (L, verapamil site) (phenylalkylamines) & - & $\mathrm{D} 600$ & 39 \\
\hline $\mathrm{K}_{\text {ATP }}^{+}$channel & - & Glibenclamide & 1.8 \\
\hline $\mathrm{SK}_{\mathrm{Ca}}^{+}$channel & - & Apamin & 0.0068 \\
\hline $\mathrm{K}^{+}{ }_{\mathrm{V}}$ channel & - & $\alpha$-dendrotoxin & 1.7 \\
\hline $\mathrm{Na}^{+}$channel (site 2) & - & Veratridine & 5200 \\
\hline $\mathrm{Cl}$ - channel & - & Picrotoxinin & 240 \\
\hline Adenosine transporter & - & NBTI & 0.52 \\
\hline Choline transporter & - & Hemicholinium-3 & 7.2 \\
\hline Dopamine transporter $(\mathrm{h})$ & - & ВTCP & 5.9 \\
\hline GABA transporter & - & Nipecotic acid & 3500 \\
\hline Norepinephrine transporter $(\mathrm{h})$ & - & Protriptyline & 14 \\
\hline Serotonin transporter $(h)$ & - & Imipramine & 3.2 \\
\hline
\end{tabular}

Table shows the inhibition $\%$ of SA13353 at $1 \mu \mathrm{M}$ and $\mathrm{IC}_{50}$ value of reference compound for each target.

$-:<50 \%$ inhibition at $1 \mu \mathrm{M}$. 

on Ischemia/Reperfusion-Induced Renal Injury in Rats

Table 1. Results of binding, enzyme inhibitory, and functional assay of SA13353 (continued)

\begin{tabular}{|c|c|c|c|}
\hline Receptor/lon Channel/Enzyme & $\%$ Inhibition at $1 \mu \mathrm{M}$ & Reference compound & $\mathrm{IC}_{50}(\mathrm{nM})$ \\
\hline $\mathrm{Ca}^{2+} /$ Calmodulin-Dep. II & - & $\mathrm{K}-252 \mathrm{a}$ & 9.2 \\
\hline $\operatorname{cox}_{1}(\mathrm{~h})$ & - & Diclofenac & 18 \\
\hline $\operatorname{cox}_{2}(h)$ & - & NS398 & 1800 \\
\hline ERK1 (h) & - & Staurosporine & 760 \\
\hline ERK2 & - & Staurosporine & 870 \\
\hline GSK3 $\beta(h)$ & - & 5-lodo-Indirubin-3'-monoxime & 0.63 \\
\hline $\mathrm{IKK} \alpha(\mathrm{h})$ & - & Staurosporine & 150 \\
\hline $\operatorname{IKK} \beta(h)$ & - & Staurosporine & 450 \\
\hline inducible NOS & - & $1400 \mathrm{~W}$ & 41 \\
\hline MEK1 & - & U0126 & 7300 \\
\hline p38 $\beta(h)$ & - & SB202190 & 21 \\
\hline p38 $\gamma(h)$ & - & Staurosporine & 260 \\
\hline p38 $(\mathrm{h})$ & - & Staurosporine & 300 \\
\hline $\mathrm{p} 70^{\mathrm{S} 6 \mathrm{~K}}(\mathrm{~h})$ & - & Staurosporine & 15 \\
\hline PKA, Non-Selective & - & $\mathrm{H}-7$ & 1800 \\
\hline PKB $\alpha /$ Akt1 (h) & - & Staurosporine & 87 \\
\hline PKC & - & Staurosporine & 190 \\
\hline PDE1 & - & 8-methoxy-IBMX & 2900 \\
\hline PDE2 (h) & - & EHNA & 6000 \\
\hline PDE3 & - & Milrinone & 880 \\
\hline PDE4 (h) & - & Rolipram & 680 \\
\hline PDE5 (h) & - & Dipyridamole & 680 \\
\hline PLA2 & - & NDGA & 49000 \\
\hline PLC & - & Neomycin & 9000 \\
\hline TACE & - & Marimastat & 4.3 \\
\hline Acetylcholinesterase (h) & - & Neostigmine & 33 \\
\hline Catechol-O-methyl transferase & - & Ro 41-0960 & 34 \\
\hline GABA transaminase & - & AoAA & 310 \\
\hline MAO-A (h) & - & Clorgyline & 13 \\
\hline MAO-B (h) & - & Deprenyl & 17 \\
\hline Phenylethanolamine-N-methyl transferase & - & LY 78335 & 73000 \\
\hline Tyrosine hydroxylase & - & 3-iodo L-tyrosine & 970 \\
\hline ATPase $\left(\mathrm{Na}^{+} / \mathrm{K}^{+}\right)$ & - & Ouabain & 450 \\
\hline AcetylCoA synthetase & - & $\mathrm{p}-\mathrm{HMB}$ & 290000 \\
\hline HMG-CoA reductase & - & Mevastatin & 4500 \\
\hline Adenylyl cyclase (basal) & - & Forskolin & $24 \mu \mathrm{M}$ \\
\hline Guanylyl cyclase (basal) & - & Sodium nitroprusside & $2.8 \mu \mathrm{M}$ \\
\hline Phosphoinositide turnover & - & PDGF-BB & $10 \mathrm{ng} / \mathrm{mL}$ \\
\hline
\end{tabular}

Table shows the inhibition $\%$ of SA13353 at $1 \mu \mathrm{M}$ and $\mathrm{IC}_{50}$ value of reference compound for each target.

$-:<50 \%$ inhibition at $1 \mu \mathrm{M}$. 
sham $(n=6)$

vehicle-treated AKI $(n=7)$
$\mathrm{AKI}+\mathrm{SA} 133533 \mathrm{mg} / \mathrm{kg} \quad(\mathrm{n}=8)$

$\mathrm{AKI}+\mathrm{SA} 1335310 \mathrm{mg} / \mathrm{kg} \quad(\mathrm{n}=9)$

$\mathrm{AKI}+\mathrm{SA} 1335330 \mathrm{mg} / \mathrm{kg} \quad(\mathrm{n}=8)$
A

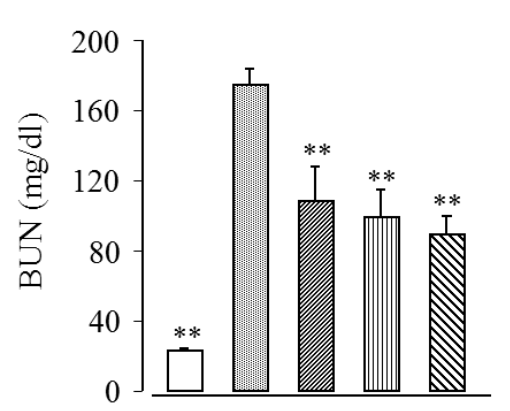

B

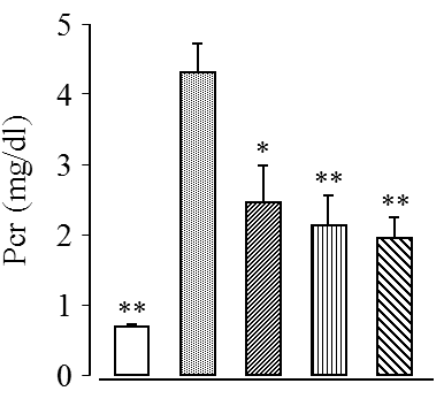

$\mathrm{C}$

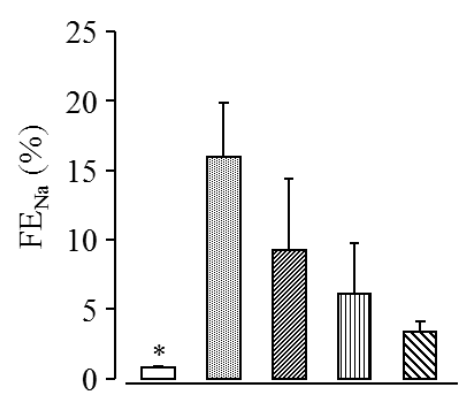

Figure 2. Effects of treatment with SA13353 on BUN (A), Pcr (B), and $\mathrm{FE}_{\mathrm{Na}}(\mathrm{C}) 24 \mathrm{~h}$ after ischemia/reperfusion. SA13353 was given orally $30 \mathrm{~min}$ before ischemia. Each column and bar represents the mean \pm S.E.M. $* P<0.05$, $* * P<0.01$, compared with vehicle-treated AKI rats.

\subsection{Renal Function after the Ischemia/Reperfusion and Effects of SA13353}

The renal function of rats subjected to 45 -min ischemia showed a marked deterioration when measured $24 \mathrm{~h}$ after the reperfusion (Figure 2). Compared with sham-operated rats, vehicle-treated AKI rats showed significant increase in BUN $(173.33 \pm 8.84$ versus $21.75 \pm 1.33 \mathrm{mg} / \mathrm{dL})$, Pcr $(4.28$ \pm 0.41 versus $0.68 \pm 0.04 \mathrm{mg} / \mathrm{dL})$, and $\mathrm{FE}_{\mathrm{Na}}(15.99 \pm 3.84$ versus $0.79 \pm 0.15 \%)$. The oral administration of SA13353 $(3,10$, and $30 \mathrm{mg} / \mathrm{kg}) 30 \mathrm{~min}$ before ischemia produced a dose-dependent preventive effect against the ischemia/reperfusion-induced renal dysfunction. When a higher dose of SA13353 (30 mg/kg) was given, renal function changes induced by ischemia/reperfusion were markedly improved (BUN, $87.74 \pm 10.91 \mathrm{mg} / \mathrm{dL}$; Pcr, 1.92 $\pm 0.29 \mathrm{mg} / \mathrm{dL} ; \mathrm{FE}_{\mathrm{Na}}, 3.40 \pm 0.70 \%$ ). The administration of SA13353 to sham-operated rats $(30 \mathrm{mg} / \mathrm{kg})$ produced no significant effects in their renal function (data not shown).

\subsection{Histological Renal Damage after the Ischemia/Reperfusion and Effects of SA13353}

Histopathological examinations revealed severe lesions in the kidney of vehicle-treated AKI rats $(24 \mathrm{~h}$ after the ischemia/reperfusion). These changes were characterized by tubular necrosis in the outer zone outer stripe of the medulla (Figures $3 \mathrm{~A}$ and $4 \mathrm{~A}$ ) (score, $4.00 \pm 0.00$ ), and medullary congestion and hemorrhage in the outer zone inner stripe of the medulla (Figures 3C and 4B) (score, $3.71 \pm 0.18$ ). Pretreatment with SA13353 at $30 \mathrm{mg} / \mathrm{kg}$ produced significant preventive effects against the development of tubular necrosis (Figures 3B and 4A), and medullary congestion and hemorrhage (Figures $3 \mathrm{D}$ and $4 \mathrm{~B}$ ). vehicle-treated AKI
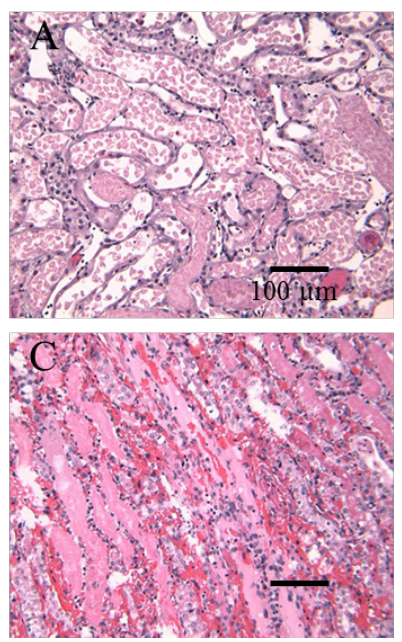

$\mathrm{AKI}+\mathrm{SA} 1335330 \mathrm{mg} / \mathrm{kg}$
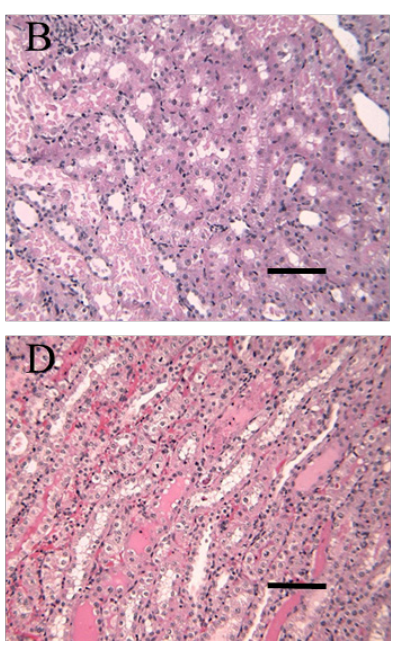

Figure 3. Light microscopy of the outer zone outer stripe (A, B) and the outer zone inner stripe $(C, D)$ of the kidney in AKI rats treated with vehicle (A, C) or $30 \mathrm{mg} / \mathrm{kg} \mathrm{SA} 13353$ (B, D) $24 \mathrm{~h}$ after ischemia/reperfusion.

SA13353 was given orally $30 \mathrm{~min}$ before ischemia. (hematoxylin and eosin staining, magnification, $\times 200)$.

\subsection{Effects of SA13353 on Renal TNF- $\alpha$, IL-10 and CINC-1 mRNA Expression after the Ischemia/Reperfusion}

Experiments to examine the effect of SA13353 treatment on TNF- $\alpha$, IL-10, and CINC-1 mRNA expression were evaluated at 2 and $4 \mathrm{~h}$ after the reperfusion. As shown in Figure 5, A and D, the increased level of renal TNF- $\alpha$ mRNA expression at 2 and $4 \mathrm{~h}$ after the ischemia/reperfusion was markedly suppressed by the treatment with SA13353. On the other hand, the administration of SA13353 tended to further augment the level of IL-10 mRNA expression at 2 and $4 \mathrm{~h}$ 
after the ischemia/reperfusion (Figure 5, B and E), although these augmentations were not statistically significant. As shown in Figure 6, A and C, the increased level of renal
CINC-1 mRNA expression at 2 and $4 \mathrm{~h}$ after the ischemia/reperfusion was partially but significantly (Figure 6C) suppressed by the treatment with SA13353.

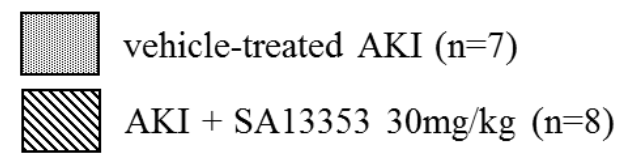

Tubular necrosis

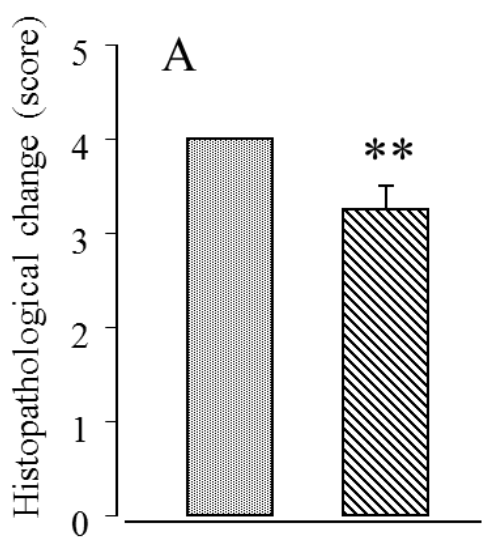

Medullary congestion

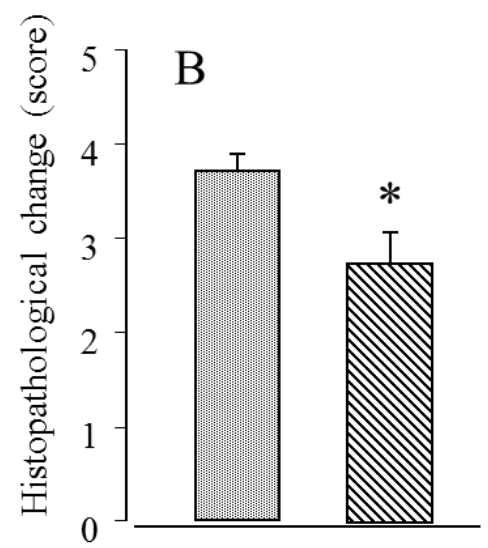

Figure 4. Effects of treatment with SA13353 (30 mg/kg) on histopathological changes (A: tubular necrosis, B: congestion and hemorrhage) in the kidneys of AKI rats. Each column and bar represents the mean \pm S.E.M. Grades of score: 0 , no change; 1 , mild; 2 , moderate; 3 , severe and 4, very severe. $* P<0.05, * * \mathrm{P}<0.01$, compared with vehicle-treated AKI rats.
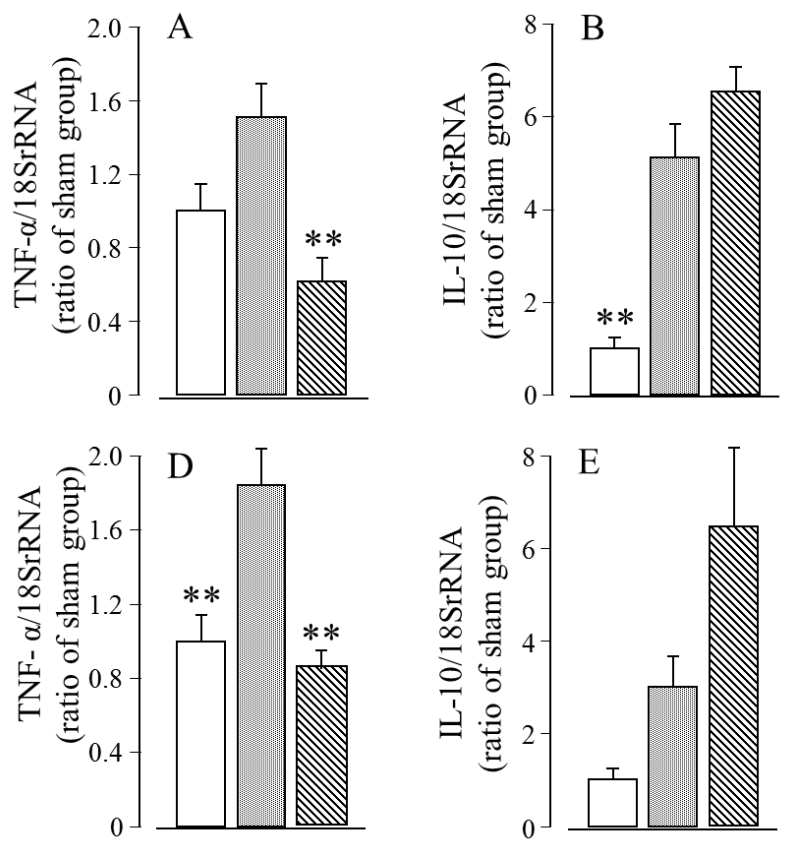

$\square$ sham $(\mathrm{n}=4 \sim 5) \quad$ VIIIII. vehicle-treated ARF $(\mathrm{n}=6)$
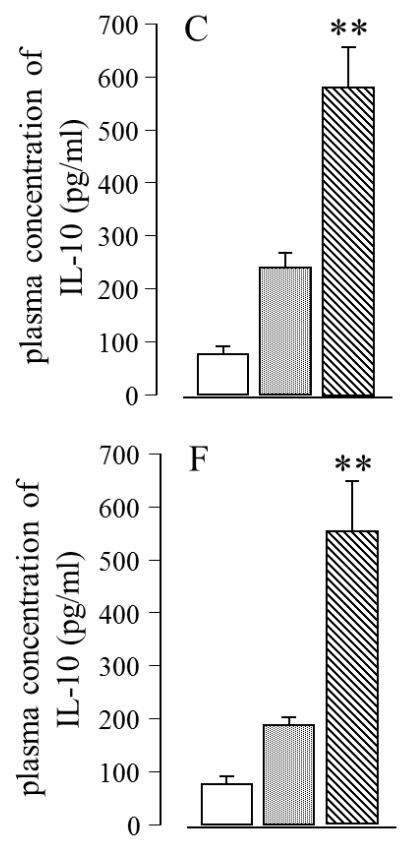

$\mathrm{ARF}+\mathrm{SA} 1335330 \mathrm{mg} / \mathrm{kg} \quad(\mathrm{n}=6)$

Figure 5. Effects of treatment with SA13353 (30 mg/kg) on renal TNF- $\alpha$ (A and D), IL-10 mRNA expressions (B and E) and plasma concentration of IL-10 (C and F) 2 (A, B and C) and 4 h (D, E and F) after the reperfusion. SA13353 was given orally 30 min before the ischemia. Each column and bar represents the mean \pm S.E.M. $* * P<0.01$, compared with vehicle-treated AKI rats. 

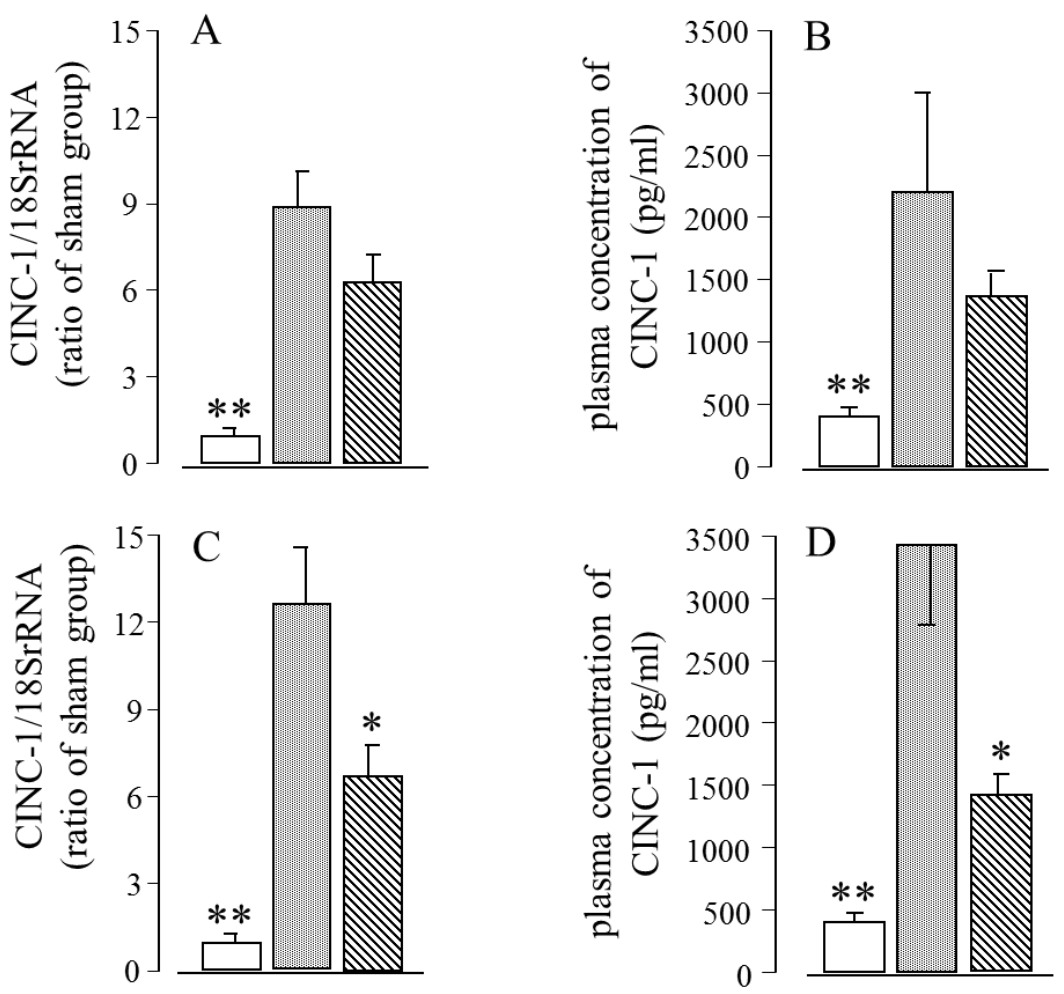

$\square \operatorname{sham}(\mathrm{n}=4 \sim 5)$

vehicle-treated AKI $(\mathrm{n}=6)$

$\mathrm{AKI}+\mathrm{SA} 1335330 \mathrm{mg} / \mathrm{kg} \quad(\mathrm{n}=6)$

Figure 6. Effects of treatment with SA13353 (30 mg/kg) on renal CINC-1 mRNA expressions (A and C) and plasma concentration of CINC-1 (B and D) 2 (A and B) and $4 \mathrm{~h}(\mathrm{C}$ and $\mathrm{D})$ after the reperfusion. SA13353 was given orally 30 min before the ischemia. Each column and bar represents the mean \pm S.E.M. $* P<0.05,{ }^{* *} P<0.01$, compared with vehicle-treated AKI rats.

\subsection{Effects of SA13353 on Plasma IL-10 and CINC-1 Concentrations after the Ischemia/Reperfusion}

Figure 5, C and F, showed the effect of SA13353 on plasma concentration of IL-10 at 2 and $4 \mathrm{~h}$ after the ischemia/reperfusion, respectively. Compared with sham-operated rats, vehicle-treated AKI rats showed 2- to 3 -fold increases in plasma concentration of IL-10, and the increased level was significantly enhanced by the SA13353 treatment. In addition, Figure 6, B and D, showed the effects of SA13353 on plasma concentration of CINC-1 at 2 and $4 \mathrm{~h}$ after the ischemia/reperfusion, respectively. Compared with sham-operated rats, vehicle-treated AKI rats showed 8.4-fold increases in plasma concentration of CINC-1 at $4 \mathrm{~h}$, and the increased level was markedly attenuated by the SA13353 treatment.

\section{Discussion}

Post-ischemic AKI is a frequent clinical syndrome with a high morbidity and mortality [2]. Reperfusion of previously ischemic renal tissue initiates a series of complex cellular events that results in injury and the eventual death of renal cells because of a combination of apoptosis and necrosis [24]. Numerous attempts have been made to prevent AKI using animal models of ischemia/reperfusion-induced renal injury, and various vasodilative agents, including natriuretic peptides, adenosine antagonists, dopamine receptor agonists, calcium antagonists, endothelin receptor antagonists, and acetylcysteine, have been considered to be useful for the prevention and management of AKI [25], although it remains to be elucidated whether similar interventions are beneficial to clinical uses. TRPV1 has also been suggested to play a role in regulating vasodilatation in a variety of vascular beds [18]. The activation of TRPV1 leads to release of several neuropeptides, such as substance $\mathrm{P}$, calcitonin gene-related peptide (CGRP), and somatostatin [26]. CGRP is strongly coexpressed in many TRPV1-expressing nerve fibers, including sensory fibers that innervate the dural vasculature [27], and it has been suggested to confer a beneficial counterbalance to the development of hypertension [28].

We have already demonstrated that TRPV1 agonists capsaicin and resiniferatoxin prevent ischemia/reperfusion-induced renal injury in rats [21]. Because the oral toxicity of capsaicin is relatively high (oral $\mathrm{LD}_{50}$ values of nearly $100-200 \mathrm{mg} / \mathrm{kg}$ in mice or rats) [29], we tried to find a safer TRPV1 agonist than capsaicin, ultimately selecting SA13353 [22] from numerous compounds available (oral $\mathrm{LD}_{50}$ values exceed $2000 \mathrm{mg} / \mathrm{kg}$ in rats). In the present study, we found that the treatment with SA13353 prevented the ischemia/reperfusion-induced renal dysfunction in rats. We have demonstrated most recently that 
SA13353 significantly inhibits lipopolysaccharide (LPS)-induced TNF- $\alpha$ production in a dose-dependent manner in rats [22]. SA13353 exhibited a binding affinity for the rat vanilloid receptor and increased neuropeptide release from the rat dorsal root ganglion neurons. However, the neuropeptide release by SA13353 was blocked by pretreatment with the TRPV1 antagonist capsazepine. Although SA13353 inhibited LPS-induced TNF- $\alpha$ production in vivo, its effect was not observed in sensory denervation rat and TRPV1 knockout mice [22]. These results suggest that SA13353 inhibits TNF- $\alpha$ production through activation of capsaicin-sensitive afferent neurons mediated via TRPV1 in vivo.

In the previous report, TRPV1 agonists markedly inhibited the neutrophil infiltration, which is one of the major causes for renal injury after ischemia/reperfusion [21]. Then, we investigated the possible inhibitory mechanisms of TRPV1 agonists on neutrophil infiltration observed in the renal tissue exposed to ischemia/reperfusion using SA13353. Expressions of adhesion molecules including intercellular adhesion molecule-1 on endothelial cells are important for neutrophil infiltration. For expression of adhesion molecules, some cytokines, including TNF- $\alpha$, have a critical role [30]. CINC-1, a major factor in acute inflammation, is responsible for the activation of neutrophils and for neutrophil chemotaxis to sites of injury [31]. On the other hand, the anti-inflammatory cytokine IL-10 has been shown recently to inhibit ischemic and cisplatin-induced AKI [7]. In addition, we have demonstrated recently that SA13353 attenuated neutrophil infiltration and the increase of TNF- $\alpha$ and CINC-1 level in lung inflammation [32]. Therefore, we investigated the effects of SA13353 on TNF- $\alpha$, CINC-1, and IL-10 mRNA expression in the postischemic kidneys. We noted that the preischemic treatment with SA13353 attenuated the ischemia/reperfusion-induced augmentation of TNF- $\alpha$ and CINC- 1 mRNA expression level. On the other hand, SA13353 further enhanced the increases in IL-10 mRNA and its serum protein levels elicited by the ischemia/reperfusion. Previous studies have demonstrated that neuropeptides such as CGRP [33-35] and somatostatin [36] inhibited the LPS-induced TNF- $\alpha$ production in vivo and in vitro. We also found recently that orally administered SA13353 evoked the release of CGRP and somatostatin [22]. Taken together, we suggest that activation of capsaicin-sensitive afferent neurons by SA13353 and the following release of neuropeptides may modify the inflammatory reactions after ischemia/reperfusion.

In separate experiments, to confirm that the preventive effects of SA13353 on ischemia/reperfusion-induced renal injury are mediated by TRPV1, we attempted to utilize TRPV1 antagonist capsazepine. However, because capsazepine itself affected the ischemia/reperfusion-induced renal injury, we could not evaluate its antagonizing activity on TRPV1 agonist-induced renoprotective effects (unpublished observations). Capsazepine is not only a TRPV1 antagonist but also inhibits voltage-activated calcium channels and nicotinic acetylcholine receptors
$[37,38]$, thereby suggesting that capsazepine is not appropriate for antagonizing study in ischemia/reperfusion-induced renal injury model. Another TRPV1 antagonist, iodo-resiniferatoxin, is also reported to be inadequate for the TRPV1 antagonizing study in vivo [39]. In a preliminary experiment, we noted that iodo-resiniferatoxin inhibited LPS-induced TNF- $\alpha$ production in rats. Thus, further studies using TRPV1 antagonists with better pharmaceutical properties or TRPV1-knockout animals are required to elucidate the TRPV1-mediated renoprotective effect and its precise mechanisms.

In the present study, SA13353 was administered before the start of 45-min ischemia. However, because AKI cannot be predicted in many clinical cases, it is important to evaluate whether TRPV1 agonists can reverse the ischemia/reperfusion-induced renal dysfunction or at least enhance the recovery process when given after the reperfusion. Therefore, we examined the effect of the postischemic treatment (at $30 \mathrm{~min}$ after the start of reperfusion) with SA13353 (30 mg/kg p.o.), but the agent produced no significant renoprotective effect (unpublished observations). SA13353 administered after the reperfusion may be unable to overcome the severe renal injury, although the reason is unknown. Further studies using a mild disease model and/or higher doses of SA13353 are required to clarify whether SA13353 treatment after the reperfusion exerts a renoprotective effect.

\section{Conclusions}

The preischemic treatment with SA13353 prevents ischemia/reperfusion-induced renal injury, probably via TRPV1-mediated mechanisms, which are closely related to the inhibition of inflammatory responses. Taken together with a previous study using capsaicin and resiniferatoxin [21], renoprotective effects by TRPV1 agonists may be useful to preserve renal function in patients with AKI after cardiac and vascular surgery.

\section{Conflict of Interests}

The authors declare that there is no conflict of interests regarding the publication of this paper.

\section{Author's Contribution}

K. Ueda and F. Tsuji contributed equally to this work.

\section{Acknowledgements}

The authors are grateful to Ms. Keiko Mizutani for her excellent technical assistance. 


\section{REFERENCES}

[1] S. Uchino, J. A. Kellum, R. Bellomo, G. S. Doig, H Morimatsu, S. Morgera, M. Schetz, I. Tan, C. Bouman, E. Macedo, N. Gibney, A. Tolwani, C. Ronco. Acute renal failure in critically ill patients: a multinational, multicenter study, The Journal of the American Medical Association, Vol.294, No.7, 813-818, 2005.

[2] K. J. Kelly and B. A. Molitoris. Acute renal failure in the new millennium: time to consider combination therapy, Seminars in Nephrology, Vol.20, No.1, 4-19, 2000.

[3] C. L. Edelstein, H. Ling, R. W. Schrier. The nature of renal cell injury, Kidney International, Vol.51, No.5, 1341-1351, 1997.

[4] K. K. Donnahoo, X. Meng, A. Ayala, M. P. Cain, A. H. Harken, D. R. Meldrum. Early kidney TNF- $\alpha$ expression mediates neutrophil infiltration and injury after renal ischemia-reperfusion, American Journal of Physiology, Vol.277, No.3, R922-R929, 1999.

[5] G. Ramesh, W. B. Reeves. Inflammatory cytokines in acute renal failure, Kidney International, Vol.66, No.S91, S56-S61, 2004.

[6] J. E. de Vries. Immunosuppressive and anti-inflammatory properties of interleukin 10, Annals of Medicine, Vol.27, No.5, 537-541, 1995.

[7] J. Deng, Y. Kohda, H. Chiao, Y. Wang, X. Hu, S. M. Hewitt, T. Miyaji, P. McLeroy, B. Nibhanupudy, S. Li, R. A. Star. Interleukin-10 inhibits ischemic and cisplatin-induced acute renal injury, Kidney International, Vol.60, No.6, 2118-2128, 2001.

[8] M. J. Caterina, M. A. Schumacher, M. Tominaga, T. A. Rosen, J. D. Levine, D. Julius. The capsaicin receptor: a heat-activated ion channel in the pain pathway, Nature, Vol.389, No.6653, 816-824, 1997.

[9] M. Van Der Stelt, V. Di Marzo. Endovanilloids: putative endogenous ligands of transient receptor potential vanilloid 1 channels, European Journal of Biochemistry, Vol.271, No.10, 1827-1834, 2004.

[10] I. Nagy, P. Sántha, G. Jancsó, L. Urbán. The role of the vanilloid (capsaicin) receptor (TRPV1) in physiology and pathology, European Journal of Pharmacology, Vol.500, No.1-3, 351-369, 2004.

[11] J. Keeble, F. Russell, B. Curtis, A. Starr, E. Pinter, S. D. Brain. Involvement of transient receptor potential vanilloid 1 in the vascular and hyperalgesic components of joint inflammation, Arthritis and Rheumatism, Vol.52, No.10, 3248-3256, 2005.

[12] Á. Szabó, Z. Helyes, K. Sándor, A. Bite, E. Pintér, J. Németh, A. Bánvölgyi, K. Bölcskei, K. Elekes, J. Szolcányi. Role of transient receptor potential vanilloid 1 receptors in adjuvant-induced chronic arthritis: in vivo study using gene-deficient mice, The Journal of Pharmacology and Experimental Therapeutics, Vol.314, No.1, 111-119, 2005.

[13] E. Y. Kissin, C. F. Freitas, I. Kissin. The effects of intraarticular resiniferatoxin in experimental knee-joint arthritis, Anesthesia \& Analgesia, Vol.101, No.5, 1433-1439, 2005.

[14] S. Demirbilek, M. O. Ersoy, S. Demirbilek, A. Karaman, N. Gürbüz, N. Bayraktar, M. Bayraktar. Small-dose capsaicin reduces systemic inflammatory responses in septic rats, Anesthesia \& Analgesia, Vol.99, No.5, 1501-1507, 2004.

[15] A. Clark, J. Keeble, E. S. Fernandes, A. Starr, L. Liang, D. Sugden, P. de Winter, S. D. Brain. The transient receptor potential vanilloid 1 (TRPV1) receptor protects against the onset of sepsis after endotoxin, The FASEB Journal, Vol.21, No.13, 3747-3755, 2007.

[16] Z. Helyes, K. Elekes, J. Németh, G. Pozsgai, K. Sándor, L. Kereskai, R. Börzsei, E. Pintér, Á. Szabó, J. Szolcsányi. Role of transient receptor potential vanilloid 1 receptors in endotoxin-induced airway inflammation in the mouse, American Journal of Physiology, Vol.292, No.5, L1173-L1181, 2007.

[17] L. Wang, D. H. Wang. TRPV1 gene knockout impairs postischemic recovery in isolated perfused heart in mice, Circulation, Vol.112, No.23, 3617-3623, 2005

[18] D. H. Wang. The vanilloid receptor and hypertension, Acta Pharmacologica Sinica, Vol.26, No.3, 286-294, 2005.

[19] N. H. Feng, H. H. Lee, J. C. Shiang, M. C. Ma. Transient receptor potential vanilloid type 1 channels act as mechanoreceptors and cause substance $\mathrm{P}$ release and sensory activation in rat kidney, American Journal of Physiology Renal Physiology, Vol.294, No.2, F316-F325, 2008.

[20] H. R. Brady, B. M. Brenner, M. R. Clarkson, W. Lieberthal. Acute renal failure, in Brenner and Rector's The Kidney, 6th edition, W. B. Saunders Co., Philadelphia, PA, 1201-1262, 2000 .

[21] K. Ueda, F. Tsuji, T. Hirata, M. Takaoka, Y. Matsumura. Preventive effect of TRPV1 agonists capsaicin and resiniferatoxin on ischemia/reperfusion-induced renal injury in rats, Journal of Cardiovascular Pharmacology, Vol.51, No.5, 513-520, 2008.

[22] M. Murai, F. Tsuji, M. Nose, I. Seki, K. Oki, C. Setoguchi, H. Suhara, M. Sasano, H. Aono. SA13353 (1-[2-(1-Adamantyl)ethyl]-1-pentyl-3-[3-(4-pyridyl)propyl]u rea) inhibits TNF- $\alpha$ production through the activation of capsaicin-sensitive afferent neurons mediated via transient receptor potential vanilloid 1 in vivo, European Journal of Pharmacology, Vol.588, No.2-3, 309-315, 2008.

[23] A. Satake, M. Takaoka, M. Nishikawa, M. Yuba, Y. Shibata, K. Okumura, K. Kitano, H. Tsutsui, K. Fujii, S. Kobuchi, M. Ohkita, Y. Matsumura. Protective effect of $17 \beta$-estradiol on ischemic acute renal failure through the PI3K/Akt/eNOS pathway, Kidney International, Vol.73, No.3, 308-317, 2008.

[24] W. Lieberthal, J. S. Levine. Mechanisms of apoptosis and its potential role in renal tubular epithelial cell injury, American Journal of Physiology, Vol.271, No.3, F477-F488, 1996.

[25] R. Venkataraman, J. A. Kellum. Novel approaches to the treatment of acute renal failure, Expert Opinion on Investigational Drugs, Vol.12, No.8, 1353-1366, 2003.

[26] S. H. Buck, T. F. Burks. The neuropharmacology of capsaicin: review of some recent observations, Pharmacologocal Review, Vol.38, No.3, 179-226, 1986.

[27] M. Dux, P. Sántha, G. Jancsó. Capsaicin-sensitive neurogenic 
sensory vasodilation in the dura mater of the rat, The Journal of Physiology, Vol.552, No.3, 859-867, 2003.

[28] I. Marquez-Rodas, F. Longo, R. P. Rothlin, G. Balfagon G. Pathophysiology and therapeutic possibilities of calcitonin gene-related peptide in hypertension, Journal of Physiology and Biochemistry, Vol.62, No.1, 45-56, 2006.

[29] A. Saito, M. Yamamoto. Acute oral toxicity of capsaicin in mice and rats, The Journal of Toxicological Science, Vol.21, No.3, 195-200, 1996.

[30] T. A. Springer. Adhesion receptors of the immune system, Nature, Vol.346, No.6283, 425-434, 1990.

[31] K. Watanabe, M. Suematsu, M. Iida, K. Takaishi, Y. Iizuka, H. Suzuki, M. Suzuki, M. Tsuchiya, S. Tsurufuji. Effect of rat $\mathrm{CINC/gro,} \mathrm{a} \mathrm{member} \mathrm{of} \mathrm{the} \mathrm{interleukin-8} \mathrm{family,} \mathrm{on}$ leukocytes in microcirculation of the rat mesentery, Experimental and Molecular Pathology, Vol.56, No.1, 60-69, 1992.

[32] F. Tsuji, M. Murai, K. Oki, H. Inoue, M. Sasano, H. Tanaka, N. Inagaki, H. Aono. Effects of SA13353, a transient receptor potential vanilloid 1 agonist, on leukocyte infiltration in lipopolysaccharide-induced acute lung injury and ovalbumin-induced allergic airway inflammation, Journal of Pharmacological Sciences, Vol.112, No.4, 487-490, 2010.

[33] Y. Feng, Y. Tang, J. Guo, X. Wang. Inhibition of LPS-induced TNF- $\alpha$ production by calcitonin gene-related peptide (CGRP) in cultured mouse peritoneal macrophages, Life Sciences, Vol.61, No.20, PL281-287, 1997.

[34] R. N. Gomes, H. C. Castro-Faria-Neto, P. T. Bozza, M. B. P. Soares, C. B. Shoemaker, J. R. David, M. T. Bozza.
Calcitonin gene-related peptide inhibits local acute inflammation and protects mice against lethal endotoxemia, Shock, Vol.24, No.6, 590-594, 2005.

[35] M. D. Harzenetter, A. R. Novotny, P. Gais, C. A. Molina, F. Altmayr, B. Holzmann. Negative regulation of TLR responses by the neuropeptide CGRP is mediated by the transcriptional repressor ICER, The Journal of Immunology, Vol.179, No.1, 607-615, 2007.

[36] J. I. Landa, J. Alvarez Sanchez, M. Grau, J. A. Sánchez, J. L. Balibrea. Somatostatin reduces the levels of tumor necrosis factor alpha in a rat model of endotoxemia induced by lipopolysaccharide, Research in Experimental Medicine, Vol.195, No.1, 317-325, 1995.

[37] R. J. Docherty, J. C. Yeats, A. S. Piper. Capsazepine block of voltage-activated calcium channels in adult rat dorsal root ganglion neurons in culture, British Journal of Pharmacology, Vol.121, No.7, 1461-1467, 1997.

[38] L. Liu, S. A. Simon. Capsazepine, a vanilloid receptor antagonist, inhibits nicotic acetylcholine receptors in rat trigeminal ganglia, Neuroscience Letters, Vol.228, No.1, 29-32, 1997.

[39] G. R. Seabrook, K. G. Sutton, W. Jarolimek, G. J. Hollingworth, S. Teague, J. Webb, N. Clark, S. Boyce, J. Kerby, Z. Ali, M. Chou, R. Middleton, G. Kaczorowski, A. B. Jones. Functional properties of the high-affinity TRPV1 (VR1) vanilloid receptor antagonist (4-hydroxy-5-iodo-3-methoxyphenylacetate ester) iode-resiniferatoxin, The Journal of Pharmacology and Experimental Therapeutics, Vol.303, No.3, 1052-1060, 2002. 